\title{
ANALISIS KEMAMPUAN PEMECAHAN MASALAH MATEMATIK SISWA SMP KELAS VII PADA MATERI HIMPUNAN
}

\author{
Rany Anggraeni ${ }^{1}$, Gida Kadarisma ${ }^{2}$ \\ ${ }^{1,2}$ IKIP Siliwangi, Jl. Terusan Jendral Sudirman, Cimahi, Jawa Barat \\ rarangr97@gmail.com
}

\begin{abstract}
This study aims to analyze and describe the mathematical problem solving abilities as well as knowing student mistakes in solving problems at the set material which is guided by whether or not the indicators of mathematical problem solving are based on Polya's procedures. In this study using a qualitative descriptive research method. Data processing technique used in analyzing the results of this data was to assess student answers based on indicators of problem solving abilities according to Polya as many as 5 questions which were a test instrument. In addition, the test results that support this research are interviews with selected students. The subjects in this study were 30 students of class VII-E in MTs Negeri 1 Cimahi. The subjects had been analyzed for this study were six. Based on the results of research conducted from 5 test questions tested, there were some errors found in the results of students answer in solving these problems, including: did not write what was known, asked, and did not describe these elements, the process of problem solving planning was not systematic, misunderstand the problem, errors in the calculation answers, irrelevant conclusions to the results, and mistakes in identifying the pictures.
\end{abstract}

Keywords: Problem Solving Ability; Based on Polya's Procedures

\begin{abstract}
Abstrak
Penelitian ini bertujuan untuk menganalisis dan mendeskripsikan kemampuan pemecahan masalah matematis serta mengetahui kesalahan siswa dalam memecahkan masalah pada materi Himpunan yang berpedoman pada terpenuhi atau tidaknya indikator pemecahan masalah matematis berdasarkan prosedur Polya. Dalam penelitian ini menggunakan metode penelitian deskriptif kualitatif. Teknik pengolahan data yang dilakukan dalam menganalisis hasil data ini yaitu dengan menilai jawaban siswa berdasarkan soal indikator kemampuan pemecahan masalah menurut Polya sebanyak 5 soal yang merupakan instrument tes. Selain hasil tes pendukung penelitian ini berupa wawancara dengan orang siswa yang terpilih. Subjek pada penelitian ini yaitu 30 siswa kelas VII-E di MTs Negeri 1 Kota Cimahi. Kemudian diambil enam subjek siswa untuk dianalisis. Berdasarkan hasil penelitian yang dilakukan dari 5 soal tes yang diujikan, masih terdapat beberapa kesalahan yang ditemukan pada hasil jawaban siswa dalam penyelesaian soal-soal pemecahan masalah ini, antara lain: tidak menuliskan apa yang telah diketahui, ditanyakan, serta tidak mendeskripsikan unsur-unsur tersebut, proses perencanaan penyelesaian soal yang tidak sistematis, tidak memahami permasalahan, kesalahan dalam perhitungan jawaban, kesimpulan yang tidak sesuai dengan hasil penyelesaian, serta kekeliruan dalam mengidentifikasi gambar.
\end{abstract}

Kata kunci: Kemampuan Pemecahan Masalah; Berdasarkan Prosedur Polya

\section{PENDAHULUAN}

Matematika dikatakan sebagai salah satu ilmu pengetahuan yang sangat penting untuk kehidupan. Hubungan matematika dengan realita kehidupan ini sangat erat kaitannya. Sejalan dengan pendapat Wulandari, Nurcahya, \& Kadarisma (2018) bahwa matematika adalah salah satu mata pelajaran yang digunakan untuk memaksimalkan kemampuan menghitung, mengukur, serta menerapkan rumus-rumus matematika pada kegiatan sehari-hari. Sehingga dijadikan sebagai mata pelajaran wajib di sekolah. 
Analisis Kemampuan Pemecahan Masalah Matematik Siswa Smp Kelas Vii Pada Materi Himpunan, Rany Anggraeni,

Pada saat seseorang melakukan aktivitas pemecahan masalah, ia juga melakukan aktivitas matematika. Kemampuan pemecahan masalah tersebut merupakan satu dari kemampuan matematis lainnya yang harus dikuasai oleh siswa, khususnya siswa jenjang sekolah menengah. Ungkapan tersebut didukung dengan pendapat yang disampaikan oleh Sumarmo (2010) bahwasanya tujuan terpenting dari pembelajaran matematika adalah adanya pemecahan masalah matematis disamping itu merupakan jantungnya matematika. Pemecahan masalah penting untuk dipelajari sebab membantu individu dalam berfikir analitik, pada hakekatnya adalah belajar berfikir bernalar, dan mengaplikasikan pengalaman dan pengetahuan yang dimiliki, berpikir kritis, kreatif, serta mengembangkan kemampuan matematis lainnya (Hendriana et al., 2017). Maka, kemampuan siswa untuk memecahkan masalah matematik sangat diperlukan guna untuk melatih cara berfikirnya, keuletan dalam menyelesaikan suatu persoalan, memiliki rasa keingintahuan yang tinggi terkait permasalahan tersebut, serta untuk melatih self confidence siswa dalam menghadapi berbagai macam situasi (Winarso, 2018).

Menurut Polya (1945) terdapat empat langkah pokok pemecahan masalah antara lain: "Understanding the problem, Devising a Plan, Carrying out the Plan, dan Looking Back". Secara terperinci keempat langkah tersebut dijabarkan sebagai berikut:

a) Understanding the Problem (Memahami Masalah)

Pada langkah ini, siswa harus memahami; Apa masalah yang dihadapi?; Apa yang ia ketahui?; Apa yang ditanyakan?; Apa kondisinya?; Bagaimana memilah kondisi tersebut?; Tulis hal-hal apa saja terkait kondisi/permasalahan tersebut, jika perlu menggunakan gambar, symbol, atau lambang yang sesuai.

b) Devising a Plan (Menyusun Rencana Pemecahan)

Langkah ini mengharapkan siswa dapat menemukan hubungan diantara data yang tersedia dengan hal-hal lain yang belum diketahui atau hal-hal yang serupa seperti masalah tersebut. Apakah pernah mengalami masalah yang saling memiliki keterikatan?; Apakah mengetahui masalah yang berkaitan? Langkah apa yang bisa digunakan?; Apakah ada pola penyelesaiannya?

c) Carrying out the Plan (Melaksanakan Rencana)

Setelah disusun, rencana tersebut harus dijalankan untuk menemukan solusinya. Melakukan pemeriksaan atas langkah yang dikerjakan apakah sudah sesuai, serta bagaimana cara membuktikan perhitungannya, langkah-langkah, serta prosedur yang digunakan sudah benar.

d) Looking Back (Memeriksa Kembali)

Melakukan pemeriksaan kembali terhadap tahapan proses dan solusi yang sudah dibuat untuk memastikan kalau cara itu sudah sangat benar. Melakukan generalisasi untuk dapat menyelesaikan permasalahan yang sama, serta mencari kemungkinan terdapatnya penyelesaian lainnya. 
Himpunan merupakan salah satu materi pokok dalam matematika SMP kelas VII semester ganjil. Dalam materi himpunan hanya mempelajari tentang konsep, tidak terdapat banyak rumus dalam materi ini, hanya saja banyak menggunakan berbagai macam simbol, notasi, dan diagram. Pentingnya mempelajari materi himpunan agar siswa mampu berfikir secara logis dan terarah. Sangat dibutuhkan juga pemahaman konsep yang baik dalam mempelajarinya (Amelia, dkk., 2016). Materi himpunan merupakan materi dasar yang dikaitkan pada kegiatan sehari-hari, tetapi sebagian siswa masih sukar dalam menguasai dan memahami materi tersebut. Menurut Sabirin (2011) bahwa kelemahan siswa pada saat memecahkan masalah antara lain karena siswa masih lemah dalam mengidentifikasi soal, memonitor proses penyelesaiannya, dan mengoreksi hasilnya. Berdasarkan pendapat dari Lusiana (2017) bahwasanya masih banyak terdapat siswa yang mengalami kesalahan dalam menyelesaikan soal materi himpunan. Adanya kesalahan tersebut perlu untuk diidentifikasi dan dicari solusinya. Permasalahan yang biasa ditemukan bahwa apa yang diberikan oleh guru kurang sesuai dengan tingkat kemampuan siswa. Seperti yang diketahui sejauh ini guru dibebankan kepada bahan ajar yang temuat dalam silabus matematika yang harus dituntaskan tepat waktu, tanpa guru perhatikan apakah siswa memahaminya atau tidak. Masalah lainnya karena siswa sering menyelesaikan persoalan pilihan ganda. Yang mana hal tersebut berdampak pada kurangnya kemampuan siwa dalam berpikir secara sistematis (Sari \& Aripin, 2018). Siswa harus dituntut untuk lebih berfikir, bekerja keras, dan harus merencanakan langkah-langkah apa saja yang harus ditempuh guna untuk memecahkan masalah secara sistematis.

Dengan dibuatnya soal-soal yang memuat indikator kemampuan pemecahan masalah matematis yang berkaitan dengan lingkungan dan kehidupan sehari-hari siswa diharapkan siswa bisa menguasai materi himpunan. Guna untuk membuat siswa merasa tertarik dan mudah menyampaikan ide-ide atau gagasannya sendiri untuk menyelesaikan soal. (Ruseffendi, 2006) menyatakan bahwa setiap persoalan merupakan problem bagi seseorang, apabila; (1) persoalan tersebut tidak dikenalinya; (2) siswa dituntut harus mampu untuk menyelesaikan persoalan tersebut, berbekal pengetahuannya sendiri ataupun kesiapan mental yang dimilikinya, entah itu terselesaikan sampai akhir jawaban atau belum; (3) persoalan tersebut merupakan pemecahan masalah baginya, jika ia memiliki niat untuk menyelesaikan permasalahannya.

Berdasarkan ulasan diatas, dengan mengetahui kemampuan siswa peneliti dapat merencanakan suatu solusi yang dapat digunakan untuk meminimalisir kesalahan yang dilakukan siswa dalam penyelesaian masalah khususnya dalam materi himpunan. Oleh karena itu, perlu adanya kesempatan untuk melakukan penelitian tentang analisis kemampuan pemecahan masalah matematik siswa SMP kelas VII pada materi himpunan yang berpedoman pada terpenuhi tidaknya indikator pemecahan masalah berdasarkan prosedur Polya. 
Analisis Kemampuan Pemecahan Masalah Matematik Siswa Smp Kelas Vii Pada Materi Himpunan, Rany Anggraeni,

\section{METODE}

Pada penelitian ini digunakan metode penelitian deskriptif kualitatif, yang bertujuan untuk menganalisis dan mendeskripsikan kemampuan pemecahan masalah matematis serta mengetahui kesalahan siswa dalam memecahkan masalah pada materi himpunan yang mengacu pada indikator pemecahan masalah matematis berdasarkan prosedur menurut Polya apakah terpenuhi atau belum. Penelitian kualitatif (naturalistic inquiry) menurut Bogdan \& Guba (Suharsaputra, 2012) adalah prosedur penelitian yang menghasilkan data deskriptif berupa kata-kata tertulis atau lisan dari orangorang dan perilaku yang diamati.

Populasi dari penelitian ini adalah seluruh siswa kelas VII Madrasah Tsanawiyah Negeri 1 Kota Cimahi yang berlokasi di Jalan Tsanawiyah No. 1 Cibeber Cimahi. Sampel yang diambil dalam penelitian ini yaitu sebanyak 30 orang siswa. Kemudian diambil secara purposive sampling sebanyak 6 siswa dengan tiga kategori, yaitu 2 siswa berkemampuan tinggi, 2 siswa berkemampuan sedang, serta 2 siswa berkemampuan rendah yang diambil sebagai subjek wawancara untuk mengeksplorasi hasil berpikirnya. Purposive sampling adalah teknik penentuan sampel dengan pertimbangan tertentu (Sugiyono, 2015).

Kegiatan pendahuluan yang dilakukan yaitu dengan meminta perijinan kepada pihak sekolah, menyampaikan maksud dan tujuan kepada guru mata pelajaran matematika untuk menentukan subjek penelitian. Teknik pengolahan data yang dilakukan dalam menganalisis hasil data ini yaitu dengan menilai jawaban siswa berdasarkan soal indikator kemampuan pemecahan masalah menurut Polya sebanyak 5 soal tes uraian yang merupakan instrument tes dengan tingkat kesukaran instrumen berada dalam kategori sedang dalam penelitan ini.

\section{Tabel 1}

Kategori Penilaian Kemampuan Pemecahan Masalah Siswa

\begin{tabular}{|c|c|}
\hline Nilai Siswa & Kategori Penilaian \\
\hline $71-100$ & Tinggi \\
\hline $41-70$ & Sedang \\
\hline $0-40$ & Rendah \\
\hline
\end{tabular}

Berikut indikator penskoran kemampuan pemecahan masalah berdasarkan prosedur Polya.

Tabel 2

Indikator Penskoran Kemampuan Pemecahan Masalah

\begin{tabular}{|c|c|c|c|}
\hline No & Aspek yang Dinilai & Reaksi Terhadap Soal/Masalah & Skor \\
\hline \multirow[t]{3}{*}{1} & \multirow[t]{3}{*}{ Memahami masalah } & - $\quad$ Tidak memahami soal/tidak ada jawaban. & 0 \\
\hline & & $\begin{array}{ll}\text { - } & \text { Tidak memperhatikan syarat-syarat soal/cara } \\
\text { interpretasi soal kurang tepat. }\end{array}$ & 1 \\
\hline & & - $\quad$ Memahami soal dengan baik. & 2 \\
\hline \multirow[t]{4}{*}{2} & \multirow{4}{*}{$\begin{array}{l}\text { Merencanakan } \\
\text { penyelesaian }\end{array}$} & - $\quad$ Tidak ada rencana strategi penyelesaian. & 0 \\
\hline & & - $\quad$ Strategi yang direncanakan kurang tepat. & 1 \\
\hline & & $\begin{array}{l}\text { - Menggunakan suatu strategi tertentu tetapi mengarah } \\
\text { pada jawaban yang salah. }\end{array}$ & 2 \\
\hline & & - Menggunakan suatu strategi tertentutetapi tidak dapat & 3 \\
\hline
\end{tabular}




\begin{tabular}{|c|c|c|c|}
\hline & & dilanjutkan. & \\
\hline & & $\begin{array}{l}\text { - } \begin{array}{l}\text { Menggunakan beberapa strategi yang benar dan } \\
\text { mengarah pada jawaban yang benar. }\end{array} \\
\end{array}$ & 4 \\
\hline \multirow[t]{5}{*}{3} & \multirow{5}{*}{$\begin{array}{l}\text { Melaksanakan rencana } \\
\text { penyelesaian }\end{array}$} & - $\quad$ Tidak ada penyelesaian. & 0 \\
\hline & & - $\quad$ Ada penyelesaian, tetapi prosedur tidak jelas. & 1 \\
\hline & & $\begin{array}{ll}\text { - } & \text { Menggunakan satu prosedur tertentu dan mengarah } \\
\text { pada jawaban yang benar. }\end{array}$ & 2 \\
\hline & & $\begin{array}{l}\text { Menggunakan satu prosedur tertentu yang benar } \\
\text { tetapi salah dalam menghitung. }\end{array}$ & 3 \\
\hline & & $\begin{array}{ll}\text { - } & \text { Menggunakan prosedur tertentu yang benar dan } \\
\text { hasilnya benar. }\end{array}$ & 4 \\
\hline \multirow[t]{4}{*}{4} & \multirow[t]{4}{*}{ Memeriksa kembali } & - $\quad$ Tidak ada pemeriksaan jawaban. & 0 \\
\hline & & - $\quad$ Pemeriksaan hanya pada jawaban (perhitungan). & 1 \\
\hline & & - $\quad$ Pemeriksaan hanya pada proses. & 2 \\
\hline & & Pemeriksaan pada proses dan jawaban. & 3 \\
\hline
\end{tabular}

Sumber: (Ariani, Hartono, Hiltrimartin, 2017)

Selain hasil tes pendukung penelitian ini berupa wawancara dengan orang siswa yang terpilih. Selanjutnya hasil tes dan hasil wawancara di analisis untuk mengetahui kesalahan/kesulitan apa yang ditemui siswa pada saat proses menyelesaikan masalah pada soal tes tersebut.

\section{HASIL}

Berdasarkan hasil penelitian yang sudah dilaksanakan dikelas VII-E MTsN 1 Kota Cimahi dengan materi himpunan. Indikator yang diterapkan peneliti ialah indikator kemampuan pemecahan masalah matematis berdasarkan prosedur menurut Polya yang terdiri atas tahapan memahami masalah, merencanakan penyelesaian, melaksanakan rencana penyelesaian, serta mengevaluasi atau memeriksa kembali.

Dalam penelitian ini, dipilih enam subjek penelitian dari 30 siswa dikelas VII-E. 6 subjek ini dipilih dari tiga kategori , yaitu berkemampuan tinggi, sedang, rendah, dan masing-masing kategori diambil 2 subjek penelitian. Pemilihan subjek analisis dipilih berdasarkan jumlah skor yang diperoleh siswa. Berdasarkan indikator penilaian pada Tabel 1, maka penentuan subjek analisis ini diurutkan berdasarkan hasil tes kemampuan pemecahan masalah siswa dari mulai yang tertinggi hingga yang terendah.

\section{Tabel 3}

Daftar Subjek Penelitian Hasil Berdasarkan Skor

\begin{tabular}{|c|c|c|c|}
\hline No & Kode Subjek & Jumlah Skor & Kategori \\
\hline 1 & CI (S1) & 100 & Tinggi \\
\hline 2 & NF $($ S2) & 76 & Tinggi \\
\hline 3 & SR(S3) & 59 & Sedang \\
\hline 4 & AN(S4) & 44 & Sedang \\
\hline 5 & RY(S5) & 17 & Rendah \\
\hline 6 & CS (S6) & 16 & Rendah \\
\hline
\end{tabular}


Analisis Kemampuan Pemecahan Masalah Matematik Siswa Smp Kelas Vii Pada Materi Himpunan, Rany Anggraeni, Gida Kadarisma

Berikut pembahasan terkait beberapa kesalahan yang dilakukan oleh subjek penelitian berdasarkan pada indikator pemecahan masalah menurut Polya.

\section{Tahap 1: Memahami Masalah}

Berdasarkan hasil jawaban oleh enam subjek penelitian terpilih, hanya S1 dan S2 yang melaksanakan tahapan ini dengan baik. Beberapa subjek penelitian masih melakukan beberapa kesalahan pada tahapan ini,. Subjek yang melakukan kesalahan tersebut adalah S3, S4, S5, dan S6.

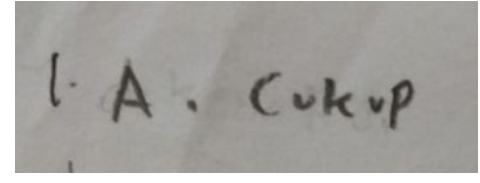

Gambar 1. Jawaban S5 soal nomor 1

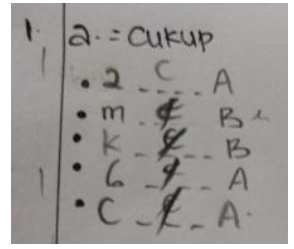

Gambar 2. Jawaban S6 soal nomor 1

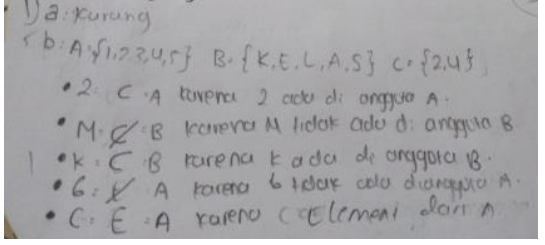

Gambar 3. Jawaban S3

soal nomor 1

Pada soal nomor 1, subjek S5 melakukan suatu kesalahan karena tidak menuliskan apa saja yang diketahui, serta apa saja yang ditanyakan dalam soal. Sedangkan S6 pada soal nomor 1 hanya menuliskan kecukupan unsurnya saja, tapi tidak mengidentifikasi masing-masing unsur yang diketahui tersebut, dan ia menjawab soal tersebut tapi mengalami kesalahan karena yang ia tuliskan belum sesuai dengan informasi yang diberikan. S3 menuliskan apa yang diketahui, ditanyakan dengan benar, serta mengidentifikasi unsur-unsur yang diketahui, akan tetapi masih mengalami kesalahan juga seperti hal nya S6.

\section{Tahap 2: Merencanakan Penyelesaian}

Pada tahapan merencanakan penyelesaian ini, hanya S1 dan S2 yang melaksanakan tahapan dengan baik, mereka sudah bisa memahami informasi dan cara apa yang harus digunakan untuk menyelesaikan persoalan yang diberikan. Kesalahan siswa pada tahapan ini dilakukan oleh S3 pada soal nomor 3 dan 4, S4 pada soal nomor 2 dan 3, S5 pada soal nomor 2,3, 4, dan 5, serta S6 pada soal nomor 3, 4, dan 5 .

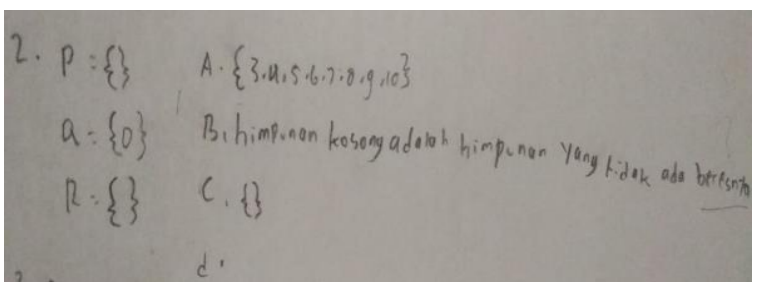

Gambar 4. Jawaban S5 soal nomor 2

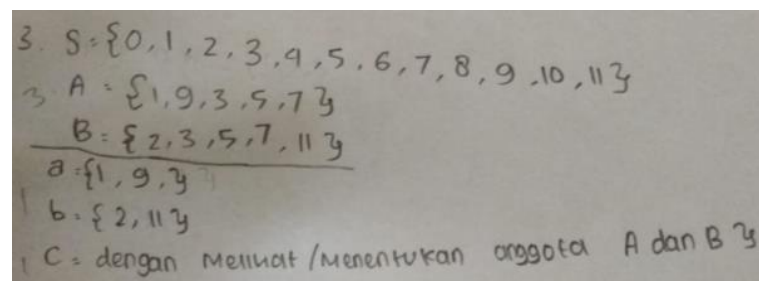

Gambar 5. Jawaban S3 soal nomor 3 
Pada soal nomor 2, terlihat S5 masih belum bisa menentukan cara untuk menentukan yang mana itu himpunan kosong, sehingga siswa mengalami kesalahan dalam proses penyelesaiannya. Terlihat pada jawaban siswa, ia belum mengerti apa itu himpunan kosong. Sedangkan S3 mengalami kesalahan pada soal nomor 3 yang mana siswa tersebut salah dalam menentukan rencana penyelesaian, ia masih kesulitan dalam menentukan cara mencari selisih dan komplemen. Adapun kesalahan tersebut dikarenakan siswa belum paham sepenuhnya materi operasi himpunan.

\section{Tahap 3: Melaksanakan Rencana Penyelesaian}

Pada tahap menyelesaikan masalah ini, siswa yang mampu mencapai tahapan ini adalah S1, S2, S3 dan S4. Namun, tak jarang siswa tersebut masih mengalami kesalahan pada soal nomor 4. Selain itu pada tahapan ini, S5 dan S6 banyak mengalami kesalahan pada semua nomor soal, dikarenakan proses penyelesaian yang ia lakukan tidak sesuai dan siswa tidak menemukan hasil yang diminta pada soal.

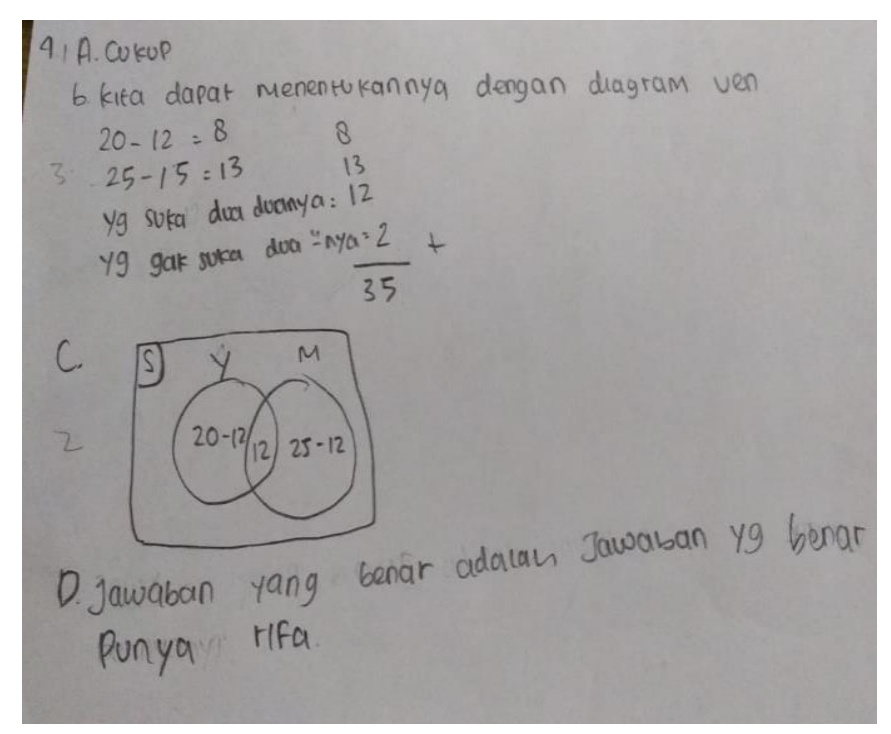

Gambar 6. Jawaban S4 soal nomor 4

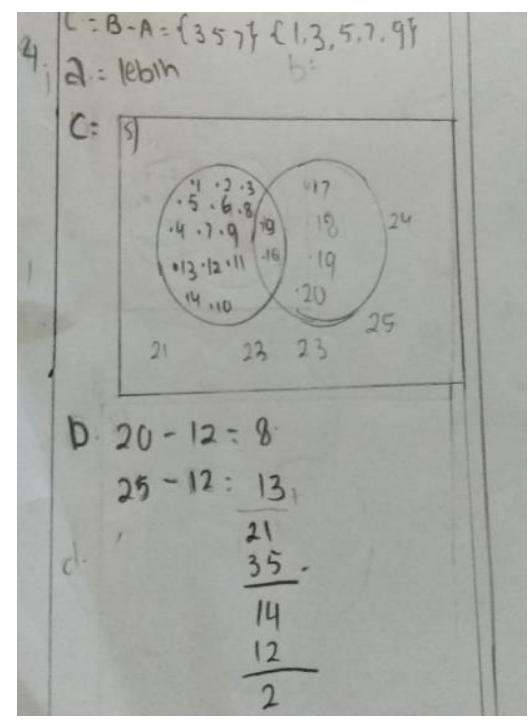

Gambar 7. Jawaban S6 soal nomor 4

Pada soal nomor 4 ini, S4 sudah menggunakan prosedur atau rencana yang benar untuk penyelesaiannya, akan tetapi pada diagram venn ia belum menuliskan berapa hasil dari pengurangan $(20$ - 12) serta $(25$ - 12). Sehingga membuatnya kebingungan untuk menyimpulkan hasilnya, dan membuatnya melakukan kesalahan perhitungan dan hasil. Sedangkan penyelesaian jawaban S6, mengalami kesalahan dikarenakan prosedur yang ia gunakan salah. Terlihat bahwa S6 mengalami kekeliruan dalam mengidentifikasi gambar diagram venn. Akan tetapi pada bagian kesimpulan siswa menjawab dengan benar.

\section{Tahap 4: Memeriksa Kembali}

Pada tahap memeriksa kembali jawaban, dilakukan oleh S1 pada semua nomor soal. Sedangkan S2, S3, S4, S5, dan S6 pada soal nomor 4 dan 5. 


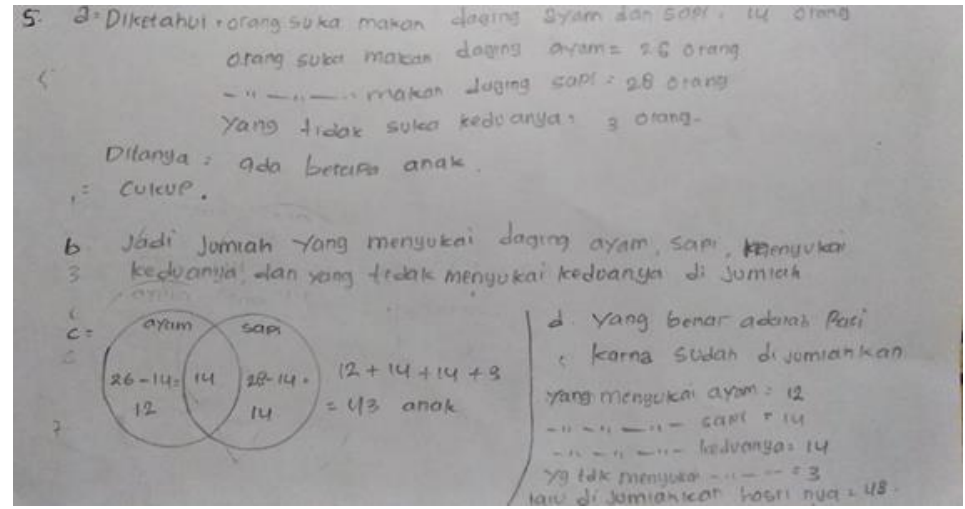

Gambar 8. Jawaban S2 soal nomor 5

Adapun kesalahan yang dilakukan oleh S2 adalah kesimpulan yang dituliskan tidak tepat, sedangkan tahapan yang dilakukan sudah hampir benar. Adapun kesalahan lainya yang terjadi pada tahapan memeriksa kembali adalah tidak menuliskan hasil kesimpulan dari pengerjaannya, tidak memeriksa kembali jawaban yang sudah diselesaikan baik pada proses maupun jawabannya.

Hasil analisis kemampuan pemecahan masalah dilapangan yang ditinjau dari hasil jawaban siswa masih terdapat mengalami kesalahan karena menurut siswa soal yang disajikan terlalu sulit, sehingga siswa sulit memahami maksud dari permasalahan dalam soal yang ditanyakan. Selain itu, siswa sulit mengidentifikasi soal tersebut sehingga siswa mengakui bahwa siswa menjawab soal dengan seadanya karena merasa bingung dan kurangnya memahami materi. Berdasarkan indikator soal kemampuan pemecahan masalah matematis, jawaban siswa belum mencapai maksimal yang terlihat dari hasil tes yang diberikan. Siswa masih kesulitan dalam menghubungkan konsep himpunan yang dipelajari sebelumnya dengan masalah yang dihadapi pada soal sehingga soal tidak terjawab sesuai yang diinginkan. Hal ini ditunjukan dalam jabawan siswa yang terdapat masih banyak jawaban yang belum sempurna dan tidak bisa menjawab dengan benar sesuai yang ditanyakan.

Berdasarkan hasil pembahasan pada tahapan memahami masalah, penyebab kesalahan siswa adalah kurangnya pemahaman akan materi himpunan, dalam hal ini siswa belum dapat membedakan yang mana itu elemen dan subset dari himpunan. Hal ini sejalan dengan pendapat Lestanti (2015) yang menyatakan bahwa dalam menyelesaikan suatu masalah, diharapkan siswa memahami dulu proses dalam menyelesaikan masalah tersebut, untuk menentukan serta mengidentifikasi konsep yang relevan, mencari generalisasinya, merumuskan rencana penyelesaiannya, kemudian siswa mengorganisasikan apa yang telah dipahami sebelumnya.

Sedangkan pada tahapan pemecahan masalah untuk merencanakan penyelesaian, penyebab kesalahan siswa adalah belum paham sepenuhnya operasi himpunan dalam mencari selisih dan komplemen. Hal ini sejalan dengan pendapat Karlimah (2010) yang menyatakan bahwa dalam merencanakan penyelesaian suatu masalah, tentukan dulu hubungan antara informasi yang diberikan dengan yang tidak diketahui untuk kemudian dapat menyelesaikannya. 
Pada tahapan melaksanakan rencana penyelesaian, penyebab kesalahan siswa adalah siswa mengalami kekeliruan dalam mengidentifikasi gambar diagram venn tapi benar dalam penyimpulan hasil akhirnya. Yuwono, Supanggih, \& Ferdiani (2018) mengemukakan bahwa memikirkan serta memahami kembali langkah demi langkah yang telah diselesaikan dalam pemecahan masalah merupakan tahap yang sangat penting untuk dapat meningkatkan kemampuan siswa dalam memecahkan suatu masalah.

Pada tahapan akhir dalam penyelesaian persoalan pemecahan masalah untuk memeriksa kembali, penyebab kesalahan siswa adalah kurang telitinya siswa dalam melakukan pengecekan sehingga masih ditemukan kesalahan-kesalahan dalam proses pemecahan masalah. Menurut Karlimah (2010) bahwasanya pada tahapan memeriksa kembali, siswa dapat melakukan kritisasi pada hasil yang sudah diperolehnya, baik pemeriksaan terhadap proses maupun jawaban (perhitungannya).

\section{KESIMPULAN}

Berdasarkan hasil analisis dan pembahasan, disimpulkan bahwa kemampuan pemecahan masalah siswa kelas VII MTs Negeri 1 Cimahi saat memecahkan persoalan himpunan secara umum sudah cukup baik namun masih mengalami kesulitan, hal ini dapat dilihat saat siswa memecahkan persoalan yang disajikan dalam soal yang diberikan, yang menjadi penyebab siswa mengalami kesulitan yaitu kurangnya pemahaman siswa untuk menjawab secara sistematis dengan menggunakan indikator kemampuan pemecahan masalah matematis. Kesimpulan dari penelitian yang dilakukan berdasarkan prosedur menurut Polya sebagai berikut.

(1) Pada tahapan yang pertama yaitu memahami permasalahan siswa dikatakan sudah mampu mencapai tahapan ini apabila siswa telah mengetahui unsur apasaja yang diketahui dan apasaja yang menjadi pertanyaan pada soal tes dengan benar.

(2) Pada tahapan yang kedua yaitu menyusun rencana penyelesaian siswa harus mengaitkan dengan pengetahuan yang sudah dimilikinya untuk menentukan strategi atau langkah yang mempermudahkannya dalam menyelesaikan soal.

(3) Pada tahapan ketiga yaitu melaksanakan rencana penyelesaian siswa dikatakan telah mampu mencapai tahapan ini apabila telah melakukan proses perhitungan jawaban sesuai apa yang direncanakan dalam tahap sebelumnya berdasarkan permintaan soal.

(4) Pada tahapan memeriksa kembali hasil jawaban tes siswa dikatakan dapat melakukan tahapan ini dengan benar apabila siswa telah mampu untuk membuat suatu kesimpulan dari hasil jawabannya dan menuliskannya dengan tepat.

Berdasarkan hasil penelitian dan kesimpulan yang disampaikan diatas, untuk penelitian selanjutnya diharapkan memberikan soal tes pemecahan masalah yang lebih bervariatif lagi yang memungkinkan banyak alternative penyelesaian jawaban, sehingga siswa dapat mengeksplor lagi kemampuannya secara lebih dalam. Untuk peneliti selanjutnya, hendaknya memperhatikan alokasi 
Analisis Kemampuan Pemecahan Masalah Matematik Siswa Smp Kelas Vii Pada Materi Himpunan, Rany Anggraeni,

waktu pembelajaran, karena pada penyelesaian permasalahan ini sangat membutuhkan waktu yang relatif lama untuk mampu mengembangkan kemampuan siswa. Maka dari itu, akan lebih baik, jika peneliti selanjutnya lebih memperhatikan pengelolaan waktu dalam pengerjaan dan dalam melaksanakan tes kemampuan pemecahan masalah supaya kegiatan penelitian bisa berjalan dengan baik, dengan hasil yang sesuai dengan harapan.

\section{DAFTAR PUSTAKA}

Amelia, D., Susanto, S., \& Fatahillah, A. (2016). Analisis Hasil Belajar Matematika Siswa Pada Pokok Bahasan Himpunan Berdasarkan Ranah Kognitif Taksonomi Bloom Kelas VII-A di SMPN 14 Jember. Jurnal Edukasi; Vol 2 No 1: Maret 2015. https://doi.org/10.19184/jukasi.v2i1.3402

Ariani, S., Hartono, Y., \& Hiltrimartin, C. (2017). Kemampuan Pemecahan Masalah Matematika Siswa Pada Pembelajaran Matematika Menggunakan Strategi AbduktifDeduktif Di Sma Negeri 1 Indralaya Utara. Jurnal Elemen, Vol. 3 No. 1, 25-34.

Hendriana, H., Rohaeti, E. E., \& Sumarmo, U. (2017). Hard Skills dan Soft Skills Matematik Siswa. In Bandung: Refika Aditama.

Karlimah. (2010). Pengembangan Kemampuan Komunikasi dan Pemecahan masalah serta Disposisi Matematis Mahasiswa PGSD melalui Pembelajaran Berbasis Masalah. Pendidikan, 11(4), 51-60.

Lestanti, M. M. (2015). Analisis Kemampuan Pemecahan Masalah Ditinjau dari Karakteristik Cara Berpikir Siswa dalam Model Problem Based Learning. UNIVERSITAS NEGERI SEMARANG.

Lusiana, R. (2017). Analisis Kesalahan Mahasiswa Dalam Memecahkan Masalah Pada Materi Himpunan Ditinjau Dari Gaya Kognitif. JPPM (Jurnal Penelitian Dan Pembelajaran Matematika), 10(1).

Polya, G. (1945). Polya's s Problem Solving Techniques. How To Solve It, 1-4.

Ruseffendi. (2006). Pengantar Kepada Membantu Guru Mengembangkan Kompetensinya dalam Pengajaran Matematika untuk Meningkatkan CBSA. In Tarsito.

Sabirin, M. (2011). Pengaruh Pembelajaran Berbasis Masalah Terhadap Kemampuan Pemecahan Masalah, Komunikasi dan Representasi Matematis Siswa SMP.

Sari, A. R., \& Aripin, U. (2018). Analisis Kesalahan Siswa Dalam Menyelesaikan Soal Cerita Bangun Datar Segiempat Ditinjau Dari Kemampuan Pemecahan Masalah Matematik Untuk Siswa Kelas Vii. JPMI (Jurnal Pembelajaran Matematika Inovatif), 1(6), 1135. https://doi.org/10.22460/jpmi.v1i6.p1135-1142

Sugiyono. (2015). Metode Penelitian Kombinasi (Mix Methods). Bandung: Alfabeta.

Suharsaputra, U. (2012). Metode Penelitian Kuantitatif, Kualitatif, Dan Aditama, Tindakan. Bandung: PT Refika Aditama.

Sumarmo, U. (2010). Berpikir Dan Disposisi Matematik: Apa, Mengapa, dan Bagaimana 
Dikembangkan pada Peserta Didik. Bandung: FPMIPA UPI.

Winarso, W. (2018). Hubungan Antara Self Confidence Dengan Kemampuan Berpikir. 1(April), 799-806. https://doi.org/10.22437/edumatica.v8i01.4623

Yuwono, T., Supanggih, M., \& Ferdiani, R. (2018). Analisis Kemampuan Pemecahan Masalah Matematika dalam Menyelesaikan Soal Cerita Berdasarkan Prosedur Polya. Jurnal Tadris Matematika, 1. https://doi.org/10.21274/jtm.2018.1.2.137-144 